\title{
KOHA 2: REVIZIJA KNJIŽNE \\ GRAĐE FAKULTETA ELEKTROTEHNIKE I \\ RAČUNARSTVA SVEUČILIŠTA U ZAGREBU
}

\author{
KOHA 2: BOOK HOLDINGS REVISION \\ AT THE FACULTY OF ELECTRICAL ENGINEERING \\ AND COMPUTING, UNIVERSITY OF ZAGREB
}

\author{
Branka Marijanović \\ Središnja knjižnica Fakulteta elektrotehnike \\ i računarstva Sveučilišta u Zagrebu \\ branka.marijanovic@fer.hr \\ Jadranka Lisek \\ Središnja knjižnica Fakulteta elektrotehnike \\ i računarstva Sveučilišta u Zagrebu \\ jadranka.lisek@fer.hr \\ Marijana Glavica \\ Knjižnica Filozofskog fakulteta Sveučilišta u Zagrebu \\ mglavica@ffzg.hr
}

\author{
UDK / UDC \\ 025.135:027.7(497.5 Zagreb) \\ Stručni rad / Professional paper \\ Prihvaćeno / Accepted: 23. 5. 2017.
}

\section{Sažetak}

Cilj je ovog rada predočiti kompleksnost provođenja revizije knjižne građe jedne visokoškolske ustanove. Tek nakon što je 2011. godine knjižnični program Koha uspješno implementiran u knjižnično poslovanje Knjižničnog sustava Fakulteta elektrotehnike i računarstva u Zagrebu, po prvi je put u 50 godina postojanja Središnje knjižnice Fakulteta provedena revizija monografskih publikacija u toj ustanovi. Naime knjižnični

Vjesnik bibliotekara Hrvatske 60, 2-3(2017), 305-316

ISSN 0507-1925

(C) VBH 2017. 
sustav FER-a čine Središnja knjižnica Fakulteta i 12 zavodskih knjižnica. Zavodske zbirke literature, kao nezaobilazan segment praćenja znanstveno-nastavne djelatnosti pojedinog zavoda, stvarane su desetljećima, dok je fond Središnje knjižnice fokusiran uglavnom na potrebe studenata. Uz raznovrsnost građe, kroz godine postojanja Fakulteta, javlja se i problem nekoordiniranosti u nabavi, pa tako i u obradi građe, što rezultira izuzetno kompleksnim i dugotrajnim procesom provođenja revizije. Rad donosi pregled čitavog revizijskog postupka te daje detaljan opis programskih karakteristika knjižničnog sustava koji je omogućio provođenje istog.

Ključne riječi: revizija knjižne građe, integrirani knjižnični sustav Koha, Fakultet elektrotehnike i računarstva Sveučilišta u Zagrebu, Središnja knjižnica FER-a

\section{Summary}

The aim of this paper is to present the complexity of library holdings revision process in a higher education institution. The revision of the library holdings of the Library of the Faculty of Electrical Engineering and Computing (FER) in Zagreb was conducted in 2011 for the first time in the 50-year of its existence. The conditions for the revision were met only after the library program Koha was successfully implemented in the library management system in 2011. The FER library system is comprised of the Faculty Central Library and 12 departmental libraries. The departmental professional literature collections have been built for decades as the vital segment in keeping track with the scientific and educational activities of the departments, while the Central library holdings have been focused mainly on the students' needs. Along with the considerable diversity of materials, throughout the years of the existence of the Faculty, the problems in managing the Library were also caused by the lack of coordination in acquisition, as well as cataloguing of the materials, which resulted in an extremely complex and lengthy process of conducting the revision. The paper provides an overview of the entire book revision process and presents a detailed description of the library system program characteristics which enabled the revision itself.

Keywords: revision of library holdings, Integrated Library System Koha, Faculty of Electrical Engineering and Computing University of Zagreb, FER Central Library

\section{Uvod}

Revizija knjižničnog fonda u jednoj visokoškolskoj ustanovi u koju su utkane polustoljetne navike poslovanja ima svoje specifičnosti koje je potrebno obrazložiti u vidu izgradnje knjižničnog fonda kroz povijest djelovanja fakulteta, razvitka studija i znanosti, ali i knjižnice kao sastavne jedinice te ustanove. 
Godine 1956. od Tehničkog fakulteta Sveučilišta u Zagrebu osnovana su 4 nova fakulteta, a među njima i Elektrotehnički fakultet (ETF) ${ }^{1}$, te je i knjižnični fond razdijeljen prema području djelovanja novonastalih sastavnica Sveučilišta u Zagrebu. Tako je ETF 1961. g. uveo prvu knjigu u inventarnu knjigu Centralne knjižnice, a ona je sadržavala sljedeće stavke: redni broj, datum upisa, autora, naslov, svezak, izdanje i format. ${ }^{2}$ Centralna knjižnica ETF-a prvotno je imala zadatak izvršiti katalogizaciju cjelokupnog fonda zavodskih knjižnica te voditi brigu o nabavi literature na zahtjev pojedinačnih zavoda. Prema Pavunić ${ }^{3}$, računi za nabavljene publikacije zavodskih knjižnica obrađivali su se u zavodima, gdje su publikacije bivale unošene i u inventarne knjige. Zavodski računi prije isplate prolazili bi kroz Centralnu knjižnicu, gdje se svaka nabavljena publikacija evidentirala te je bila unesena u centralni katalog. Prema statistici iz $1957 .{ }^{4}$ bilo je $u$ 11 zavoda 6500 svezaka, od toga 4500 svezaka knjiga i 2000 svezaka časopisa. Godine 1961. oko Centralne je knjižnice okupljeno i 12 zavodskih knjižnica, budući da se broj zavoda na Fakultetu povećao, te Pavunić ističe ${ }^{5}$ da je bilo potrebno organizirati funkcionalan odnos između njih.

Međutim, kako navodi Pavunić 6 , s vremenom se pokazalo da odnos Centralne knjižnice i zavodskih knjižnica nije bio koordiniran. Nabava se vršila zasebno i bez dogovora.

Prema tome, u godinama koje su uslijedile Centralna je knjižnica deklarativno imala "stručni nadzor" nad radom zavodskih knjižnica: pokušaj objedinjavanja fondova bilo je uvođenje knjižničnog programa FERLIB. ${ }^{7}$ No sve do Odluke o reviziji navedeno se nije provodilo u praksi. Budući da su se knjige nabavljale sredstvima zavodâ ili projektima pojedinih nositelja, smatralo se da je to isključivo njihovo vlasništvo i da imaju sva prava činiti s tom građom ono što smatraju primjerenim za svoju upotrebu. Zbog takva načina razmišljanja i djelovanja stvarale su se miniknjižnične zbirke (cca 500 naslova) izuzetno vrijednih i skupih naslova koji su obrađivali određenu temu istraživanja i bili razmješteni po sobama djelatnika tog tematskog tima (zato na pojedinom zavodu postoji i

\footnotetext{
1 Spomenica - 40. obljetnica Fakulteta elektrotehnike i računarstva : 1956. - 1996. Zagreb : Fakultet elektrotehnike i računarstva, 1996. Str. 10.

2 Pola stoljeća nam je tek : 1961.-2011. : spomenica Središnje knjižnice Fakulteta elektrotehnike i računarstva. Zagreb : Fakultet elektrotehnike i računarstva, 2011. Str. 3

3 Pavunić Marija. Struktura i djelovanje knjižnice Elektrotehničkog fakulteta u Zagrebu : magistarski rad. Zagreb : Prirodoslovno-matematički fakultet u Zagrebu, 1966. Str. 16.

4 Isto.

5 Isto, str. 18.

6 Isto, str. 8.

7 Zavodi su knjižničnu građu davali na unos tek djelomično jer su smatrali da je to njihovo vlasništvo i da ne mora biti uključeno u zajednički računalni katalog.
} 
nekoliko takvih zbirki, gdje je svaki nositelj imao svoj stav o tome kako postupati $\mathrm{s}$,njihovom“ građom). ${ }^{8}$

Zavodske zbirke literature kao nezaobilazan segment praćenja znanstveno-nastavne djelatnosti stvarane su godinama, prateći nastavne programe i znanstveni interes pojedinog zavoda. Tako se tijekom procesa razvoja same znanosti stvaraju i unutar samog zavoda znanstvene tematske podskupine, a ta se literatura prikuplja oko pojedinih timova znanstvenika, tako da su nastale podjele fondova i unutar samih zavodskih zbirki. Često se spominje kako su znatna sredstva godinama ulagana u povećanje fundusa knjižnica, a mnoge od zavodskih knjižnica predstavljaju matičnu zbirku knjiga iz područja kojim se određeni zavod bavi.

Godine 1995. nastao je i sasvim nov dio Fakulteta - računarstvo, tj. Elektrotehnički fakultet postaje Fakultet elektrotehnike i računarstva (FER), u sklopu kojega je uveden poseban studij računarstva i u dodiplomskoj nastavi, tako da je novim nastavnim planom FER-a predviđeno stjecanje stupnja diplomiranog inženjera računarstva ${ }^{9}$. Danas knjižnični sustav Fakulteta elektrotehnike i računarstva čine Središnja knjižnica Fakulteta kao ustrojbena jedinica te knjižnice zavodâ (12 zavoda) kao dio djelatnosti zavodâ. Stručni nadzor nad knjižnicama zavodâ obavlja Središnja knjižnica Fakulteta, koja evidentira ukupan knjižnični fond Fakulteta, pa tako i fond koji je smješten po zavodima, a s ciljem stvaranja jedinstvene online baze knjižničnog fonda Fakulteta. ${ }^{10}$

Neke knjižnice zavodâ imale su uredno vođene inventarne knjige, a neke ne. Primjerice Zavod za automatiku i računalno inženjerstvo (ZARI; nekadašnji Zavod za regulacionu i signalnu tehniku, utemeljen 1954. godine) bio je zavod s najbolje uređenim inventarnim knjigama, što bi se moglo objasniti činjenicom da je tajnica tog zavoda položila stručni ispit za pomoćnog knjižničara. Kako je Središnja knjižnica bila na kraju svake kalendarske godine dužna upravi predati izvješće o brojčanom stanju knjiga ${ }^{11}$, svaki bi zavod sastavio popis, a takvo izvješće potvrdio bi predstojnik zavoda. U Središnju knjižnicu dostavljala bi se inventurna lista ${ }^{12}$ koja se temeljila ili na podatku iz inventarne knjige ili na procjeni o broju primjeraka monografskih publikacija kojim određeni zavod raspolaže u tom trenutku. Sama revizija pokazat će da je takvo procjenjivanje doista bilo „samoprocjenjivanje“, budući da su brojčani pokazatelji bili sasvim drukčiji.

\footnotetext{
8 Pokazalo se da je upravo takav ,razmještaj“ knjižne građe rezultirao gubljenjem velikog broja naslova, jer je odlaskom određenog djelatnika s FER-a odlazio i taj knjižnični fond.

9 Spomenica - 40. obljetnica. Nav. dj., str. 11.

10 Pravilnik o Knjižnici FER-a, čl. 6. Zagreb: Knjižnica, 2002. (Interni dokument)

11 Dio obvezne Inventure vezane uz financijsko poslovanje.

12 Inventura, $t \mathrm{j}$. inventurna lista - popis svih sredstava (imovine) i obveza prema izvorima sredstava radi usklađivanja stvarnog stanja s knjigovodstvenim stanjem. (Usp. Poslovni rječnik Zagreb: Masmedia, 1992. Str 194.). Inventarna knjiga - popis inventara, tj. brojeva dodijeljenih knjižnoj građi (svaki primjerak knjižne građe obilježen je svojim inventarnim brojem).
} 


\section{Revizija monografskih publikacija u Knjižničnom sustavu FER-a}

Prema odredbama članka 2. Pravilnika o reviziji i otpisu knjižnične građe ${ }^{13}$, knjižnice su obvezne provoditi redovite revizije svojih fondova knjižnične građe periodično, ovisno o obimu knjižnične građe, i to za knjižnice do 100000 jedinica knjižnične građe svakih osam godina. I sam Pravilnik o Knjižnici FER-a ${ }^{14}$ ističe kako se pod revizijom podrazumijeva provjera brojčanog stanja bibliotečne građe, a ukoliko postoji izgubljena građa koja na reviziji nije bila na uvidu, potrebno je pokrenuti postupak otpisa.

Godine 1994. Središnja knjižnica FER-a počela je koristiti program za knjižnično poslovanje FERLIB koji je objedinjavao sve knjižnice na Fakultetu ${ }^{15}$, no kako knjižnični program nije bio prilagođavan novonastalim okolnostima u knjižničarstvu, cjelokupno je knjižnično poslovanje Fakulteta 2011. godine prebačeno na novi program - integrirani knjižnični softver Koha. Prvi uvjet za pokretanje postupka revizije bio je upravo taj - osigurati da se svi relevantni podaci o knjižničnom fondu cijelog Fakulteta nalaze u knjižničnom programu koji podržava provedbu revizije.

Nakon što je krajem lipnja 2011. godine program Koha uspješno implementiran u knjižnično poslovanje Knjižničnog sustava FER-a, 1. srpnja iste godine započet je postupak revizije. Knjižni fond za koji je bilo potrebno provesti reviziju obuhvaćao je fond Središnje knjižnice te fondove dvanaest zavodskih knjižnica Fakulteta i knjiga smještenih u CIP-u. ${ }^{16}$ Cjelokupan fond brojio je 76232 primjerka. Revizija se provodila i za vrijeme kolektivnog godišnjeg odmora tijekom ljeta 2011. i 2012. godine, a u njezinu provođenju sudjelovalo je 7 djelatnika, ali u različitim razdobljima (4 u stalnom radnom odnosu; 1 osoba zaposlena kao ispomoć u reviziji tijekom 11 mjeseci (VSS); 1 osoba kao ispomoć u reviziji na 1 mjesec (VSS); 1 osoba na stručnom osposobljavanju za rad u knjižnici tijekom 12 mjeseci (VSS)). Revizija je formalno završena 20. prosinca 2012. godine.

\subsection{Programske karakteristike knjižničnog sustava Koha}

Knjižnični softver Koha ima dva alata koji se mogu upotrijebiti prilikom revizije. Prvi je alat za inventuru, a drugi je općenitiji i služi za promjenu podataka o primjercima na kojima su u Kohi zapisani podaci o posjedovanju građe. Os-

13 Pravilnik o reviziji i otpisu knjižnične građe. // Narodne novine 21, 503(2002). [citirano: 2015-01-15.]. Dostupno na http://narodne-novine.nn.hr/clanci/sluzbeni/2002_03_21_503.html.

14 Pravilnik o Knjižnici. Nav. dj., čl. 24.

15 Pola stoljeća. Nav. dj., str. 64.

16 Centar informacijske potpore nije imao knjižnicu, već su knjige bile ciljano kupovane djelatnicima te ustrojbene jedinice za rad na određenoj problematici, tj. zadatku koji su rješavali da bi sustav potpore cjelokupnoj djelatnosti FER-a bio što učinkovitiji. 
novni podatak koji je potrebno zabilježiti na primjerak prilikom inventure jest datum kada je građa viđena ili zatečena u knjižnici. Osim toga, potrebno je označiti izgubljene primjerke i primjerke koje želimo otpisati zajedno s razlogom otpisa, za što u Kohi postoje posebni statusi. Prema datumu kada je građa zadnji put viđena mogu se izraditi izvještaji iz kataloga iz kojih se saznaje koliko je primjeraka prošlo inventuru u određenom razdoblju. Kada se u takav izvještaj dodaju još i podaci o statusu primjeraka - izgubljeno i otpisano (zajedno s razlogom otpisa) - dobivaju se popisi potrebni za reviziju fonda.

Alat za inventuru omogućuje dva načina rada - korištenje datoteke koja sadrži bar-kodove ili označavanje primjeraka kroz rezultate pretraživanja prema različitim kriterijima. Datoteku s bar-kodovima dobivamo tako da uz pomoć čitača očitamo bar-kodove primjeraka građe i zapisujemo ih u tekstualnu datoteku. Takvu datoteku možemo učitati u Kohu i odrediti datum inventure, a alat će automatski na sve primjerke čiji su bar-kodovi zapisani u toj datoteci upisati datum koji odredimo kao datum inventure. U drugom načinu rada omogućeno nam je da na ekranu prikažemo sve primjerke iz pojedine knjižnice na određenoj lokaciji i u određenom rasponu signatura. Takav popis možemo dodatno ograničiti prema statusima primjeraka (nije za posudbu, izgubljeno ili oštećeno), a možemo i s popisa isključiti sve primjerke koji su trenutno u posudbi. Primjerci građe na tom popisu bit će automatski poredani prema signaturama, a od podataka će biti prikazani bar-kod, signatura, naslov, autor i datum kada je jedinica zadnji put viđena. Na početku popisa nalazi se okvir koji označavamo za one primjerke koji se nalaze u knjižnici i za koje će se nakon naše potvrde u bazu zabilježiti da je primjerak zadnji put viđen na današnji datum.

Drugi je alat općenitiji i omogućuje promjenu bilo kojeg podatka o primjerku za niz bar-kodova zabilježenih u tekstualnoj datoteci ili je bar-kodove moguće učitati izravno u sučelje programa. Tijekom revizije fonda FER-ovih knjižnica koristili smo taj alat, i to na način da su bar-kodovi zatečenih primjeraka učitavani $u$ datoteke koje su se nakon toga učitavale u Kohu. Naime osim podatka o datumu kada je primjerak zatečen u knjižnici (zadnji put viđeno) trebalo je revidirati i podatke o lokacijama primjeraka. U programu FERLIB podatak o lokaciji bilježen je vrlo granularno i nesustavno, što je za rezultat imalo oko 200 lokacija zabilježenih u katalogu. Podaci su migrirani u Kohu s podatkom o lokaciji kakav je bio zabilježen u programu FERLIB, ali je u Kohi određen ograničen broj lokacija koje se mogu dodijeliti primjercima. Osim toga, neki su primjerci i mijenjali lokaciju (npr. knjige iz zavodskih knjižnica koje su sada smještene u zajedničkom spremištu koje koriste svi zavodi FER-a za pohranjivanje izlučene knjižnične građe), pa je i taj podatak o novoj lokaciji trebalo što jednostavnije zabilježiti. Nakon učitavanja datoteke s bar-kodovima alat prikazuje sučelje na kojem je prikazan popis primjeraka s bar-kodovima iz učitane datoteke te nudi mogućnost 
promjene podataka za te primjerke. Za očitavanje bar-kodova koristili smo čitače koje je FER već posjedovao i koristio za inventuru imovine. Radilo se o čitačima koji su imali instaliran operativni sustav Windows i mogućnost snimanja očitanih bar-kodova u datoteku Microsoft OneNote Mobile koju je bilo moguće presnimiti na osobno računalo. Tu je datoteku prije učitavanja u Kohu trebalo konvertirati u tekstni format, za što je napisana skripta kako bi se konverzija odvijala automatski. Dogovorili smo se da datoteke s očitanim bar-kodovima u nazivu sadrže lokaciju i datum očitavanja, prema čemu se znalo koje podatke na primjerku treba promijeniti za određenu skupinu bar-kodova.

Osim uz pomoć spomenutih dvaju alata, datum kada je primjerak građe zadnji put viđen u knjižnici zapisuje se i prilikom svake transakcije posudbe ili vraćanja primjerka. To znači da se tijekom inventure i revizije posudba može nesmetano odvijati. Također, to omogućuje još jedan način označavanja primjeraka građe koji su zatečeni u knjižnici tijekom revizije - umjesto u tekstnu datoteku, bar-kodove primjeraka moguće je učitavati izravno u sučelje za vraćanje građe. ${ }^{17}$ Takav način rada može biti praktičan ako prilikom inventure koristimo pokretni uređaj s ugrađenim čitačem za bar-kod koji ujedno ima i vezu s internetom te web-preglednik u kojem se može otvoriti sučelje programa Koha.

\subsection{Revizija u Središnjoj knjižnici FER-a}

Početkom srpnja 2011. godine djelatnici su započeli s revizijom u Središnjoj knjižnici. Budući da je fond bio u potpunosti kodiran, revizija se odvijala bez problema. No zbog obima poslova s korisnicima (na početku akademske godine), posao se oduljio od srpnja 2011. do listopada 2012., a obrađeno je 34226 primjeraka.

Svi primjerci koji nisu zatečeni u knjižnici za vrijeme revizije ili, tehnički gledano, svi primjerci koji su obilježeni kao viđeni nakon datuma kada je započeta revizija, označeni su kao izgubljeni. To je bilo moguće učiniti uz pomoć alata za skupnu promjenu podataka o primjercima na način da se najprije uz pomoć modula za izvještaje u tekstnu datoteku snime bar-kodovi takvih primjeraka, nakon čega se ta datoteka učita u Kohu uz pomoć alata za promjenu podataka o primjercima u skupini te se za te primjerke odrede odgovarajući podaci o statusima.

\subsection{Revizija u zavodskim knjižnicama}

Od rujna 2011. godine djelatnici su započeli reviziju po knjižnicama zavodâ:

1. Zavod za primijenjenu matematiku (ZPM): knjižni fond bio je resigniran prije provođenja revizije. Naime profesori matematike zahtijevali su da

$17 \mathrm{Na}$ engleskom se jeziku funkcija za vraćanje građe naziva check-in, što je općenitiji pojam od „vraćanja“ ili „razduživanja“, kako se to najčešće prevodi na hrvatski. 
njihov fond bude raspoređen po matematičkoj klasifikaciji pod nazivom Mathematics Subject Classification (MSC). ${ }^{18} \mathrm{Uz}$ resigniranje, svaki primjerak knjiga knjižničari su i kodirali, pa je stoga taj dio građe bio vrlo brzo revidiran. No dio fonda bio je izlučen i smješten u spremištu koje koriste svi zavodi FER-a za pohranjivanje izlučene knjižnične građe. Taj dio fonda zadržao je numerus currens poredak knjiga na policama i nije bio kodiran. Stoga je trebalo programirati ispis kodova samo za te primjerke.

2. Zavod za elektrostrojarstvo i automatizaciju (ZESA): knjižnični fond bio je računalno obrađen $u$ dva različita programska rješenja: jedan dio fonda bio je u FERLIB-u, a noviji dio građe obrađen je $\mathrm{u}$ internom programu (aplikacija dBase). No kako se u konverziji mogao koristiti samo dio iz FERLIB-a, ispostavilo se da onaj drugi dio uopće nije moguće konvertirati jer nije zadovoljavao ni minimum standarda bibliografskih zapisa. Mogućnost preuzimanja zapisa i tu je pokazala svu svoju učinkovitost te je 1005 primjeraka knjiga računalno obrađeno i kodirano u relativno kratkom razdoblju (s obzirom na zatečenu situaciju na Zavodu) od listopada 2011. do lipnja 2012. godine.

3. Zavod za telekomunikacije (ZTEL): revizija je trajala od listopada 2011. do ožujka 2012., a obrađen je 4041 primjerak knjiga.

4. Zavod za primijenjenu fiziku (ZPF): revizija je trajala od rujna 2012. do prosinca $2012 .{ }^{19}$, a obrađeno 2827 primjeraka.

5. Zavod za osnove elektrotehnike i električka mjerenja (ZOEM): revizija je trajala od listopada 2011. do studenog 2012., a obrađena su 2382 primjerka (2010. g. evidentirano je 3818 primjeraka).

6. Zavod za visoki napon i energetiku (ZVNE): revizija je trajala od listopada 2011. do studenog 2012., a obrađeno je 3319 primjeraka.

7. Zavod za elektroničke sustave i obradbu informacija (ZESOI): revizija je trajala od listopada 2011. do lipnja 2012., a obrađeno je 3969 primjeraka (2010. evidentirano je 3577 primjeraka).

8. Zavod za automatiku i računalno inženjerstvo (ZARI): revizija je trajala od rujna 2012. do listopada 2012., a obrađena su 733 primjerka. (2010. g. evidentirano je 2570 primjeraka).

9. Zavod za elektroakustiku (ZEA) - revizija je trajala od studenog 2011. do travnja 2012., a obrađeno je 1288 primjeraka (2010. g. evidentirana su 2463 primjerka).

182010 Mathematics Subject Classification. [citirano: 2015-01-11.]. Dostupno na http://www. ams.org $/ \mathrm{msc} / \mathrm{msc} 2010 . \mathrm{html}$.

19 Obim poslova u Središnjoj knjižnici u tom je razdoblju omogućio da više djelatnika radi na poslovima revizije, te je stoga revizija na nekim zavodima završila relativno brzo. 
10. Zavod za elektroniku, mikroelektroniku, računalne i inteligentne sustave (ZEMRIS) - revizija je trajala od rujna 2012. do prosinca 2012. g., a obrađeno je 2445 primjeraka (2010. g. evidentiran je 5001 primjerak).

11. Zavod za radiokomunikacije (ZRK): revizija je trajala od ožujka 2012. do listopada 2012. g., a obrađena su 2352 primjerka (2010. g. evidentirano je 3165 primjeraka).

12. Zavod za primijenjeno računarstvo (ZPR) nije imao evidentiranu knjižnu građu.

Sve knjige koje su bile dostupne djelatnici Središnje knjižnice unijeli su u računalni katalog, stručno obradili i kodirali te one čine dio mrežnog Knjižničnog sustava FER-a. Po završetku revizije djelatnici su izradili skupni zapisnik o reviziji, pa tako i zapisnik za svaku jedinicu (knjižnicu) unutar Fakulteta koju su obrađivali. U svakom je zapisniku navedeno razdoblje u kojem je provedena revizija, podatak o aktivnom knjižnom fondu, podatak o izgubljenim knjigama te podatak o vrijednosti knjiga predloženih za otpis. Zapisnik je potpisan od strane predstojnika zavoda, djelatnika zavoda zaduženog za provedbu revizije, djelatnika Središnje knjižnice koji su provodili reviziju te voditeljice Središnje knjižnice. Kao prilog zapisniku predan je i CD-ROM na kojem je bio naveden popis naslova knjiga koje se nalaze $u$ fondu te popis naslova koji se smatraju izgubljenima. ${ }^{20} \mathrm{Ta}-$ blica 1 prikazuje Skupni zapisnik o reviziji koji donosi podatke za sve zavodske knjižnice i Središnju knjižnicu Fakulteta po završetku postupka revizije, dok slika 1 prikazuje Zapisnik o reviziji knjižne građe Središnje knjižnice FER-a.

Bitno se razlikuju podaci iz inventurnih lista knjižnica FER-a (stanje na dan 31. prosinca 2011. godine jest 76232 sveska - od računalno evidentiranog broja primjeraka knjiga (stanje na dan 20. prosinca 2012. godine jest 64591 svezak). U postupku revizije otpisano je 10457 primjeraka, novoupisanih je naslova 10556 , dopunjenih kataložnih zapisa 9098, dok knjižni fond FER-a broji 5004 primjerka knjiga na pismima različitim od latinice. Tablica 2 prikazuje broj primjeraka koji su obrađeni u postupku revizije, a koji su napisani pismima različitim od latinice.

Zbog vremenskih rokova i manjka djelatnika neki su se poslovi (kao što je otpisivanje građe u programu Koha) nastavili i mjesecima nakon samog postupka revizije.

\footnotetext{
20 Broj knjiga koje nisu viđene velik je zbog čestih prekida u programskoj komunikaciji Središnje knjižnice i Studentske službe - studenti su se ispisivali/odlazili s FER-a, a da nisu vratili zadužene knjige; mnoge su knjige izgubljene, dok su s druge strane mnoge knjige koje nikada nisu unesene u katalog ili inventurnu listu pronađene po kabinetima i policama zavodskih knjižnica.
} 
Tablica 1. Skupni zapisnik o reviziji ${ }^{21}$

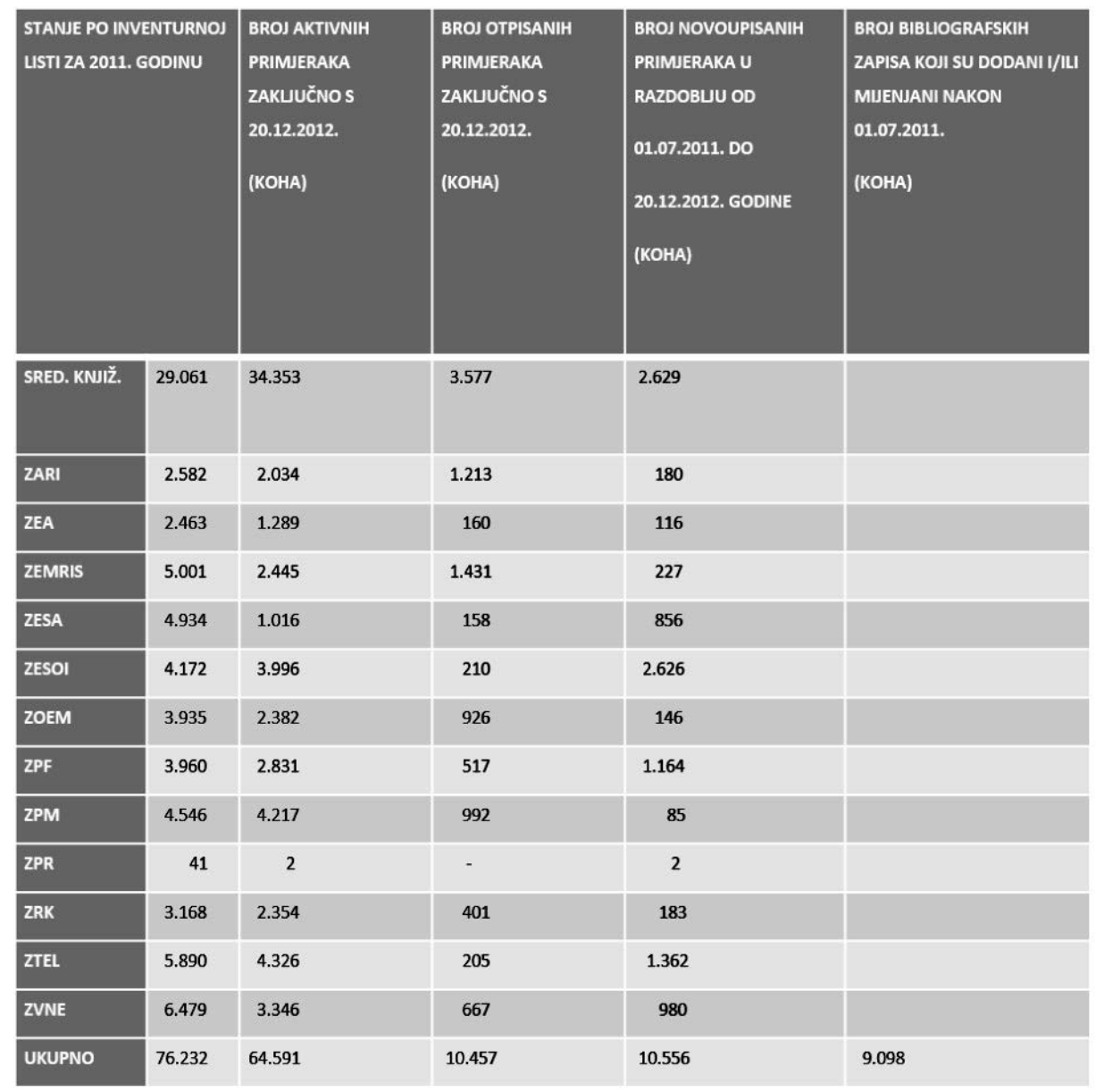

Tablica 2. Broj primjeraka na pismima različitim od latinice

\begin{tabular}{llllllll}
$\begin{array}{lllll}\text { RUSKA } \\
\text { ĆIRILICA }\end{array}$ & $\begin{array}{l}\text { SRPSKA } \\
\text { ĆIRILICA }\end{array}$ & $\begin{array}{l}\text { MAKEDONSKA } \\
\text { ĆIRILICA }\end{array}$ & $\underline{\text { CIRILICA }}$ & $\underline{\text { GOTICA }}$ & $\begin{array}{l}\text { GRČKO } \\
\text { PISMO }\end{array}$ & $\begin{array}{l}\text { KINESKO } \\
\text { PISMO }\end{array}$ & $\begin{array}{l}\text { ARAPSKO } \\
\text { PISMO }\end{array}$ \\
\hline$\underline{4.762}$ & $\underline{185}$ & $\underline{8}$ & $\underline{17}$ & $\underline{27}$ & $\underline{3}$ & $\underline{1}$ & $\underline{1}$ \\
\hline
\end{tabular}

21 Navodi se broj otpisanih primjeraka do 20. prosinca 2012., kada je zbog kraja kalendarske godine Upravi Fakulteta službeno predan izvještaj o provedenoj reviziji; proces otpisivanja primjeraka koji nisu pronađeni nastavio se u mjesecima koji su uslijedili. 
Fakultet elektrotehnike i računarstva

Središnja knjižnica

Zagreb, Unska 3

U Zagrebu, 08.11.2012.

\section{Fakultet elektrotehnike i računarstva}

\section{Predmet: revizija knjižne građe Središnje knjižnice}

Prema odredbama članka 2. Pravilnika o reviziji i otpisu knjižnične građe (Narodne novine br. 21/2002), knjižnice su obvezne provoditi redovite revizije svojih fondova knjižnične građe periodično, ovisno o obimu knjižnične građe i to za knjižnice do 100.000 jedinica knjižnične građe svakih osam godina. U skladu s tim odredbama, od srpnja 2011. do listopada 2012. godine provedena je revizija knjižne građe Središnje knjižnice Fakulteta elektrotehnike i računarstva Sveučilišta u Zagrebu. Slijedom te radnje zaključuje se sljedeće:

- aktivni knjižnični fond čini $\mathbf{3 4 . 2 2 6}$ primjeraka knjiga

- 3585 knjige nisu viđene u procesu revizije (smatraju se izgubljenima)

- vrijednost knjiga predloženih za otpis (po osnovi izgubljenosti) $=0$ kn

Sve knjige koje su bile dostupne unijete su u računalni katalog, stručno obrađene, kodirane i čine dio mrežnog Knjižničnog sustava FER-a. Na CD-u, u prilogu ovom dopisu, nalazi se popis naslova knjiga koje su u fondu Središnje knjižnice i popis naslova koji se smatraju izgubljenim.

Napomena: broj knjiga koje nisu videne velik je zbog cestih prekida u programskoj komunikaciji Središnje knjižnice i Studentske službe - studenti su se ispisivali/odlazili s FER-a a da nisu vratili zadužene knjige.

Djelatnici Središnje knjižnice koji su provodili reviziju:

Dina Vrkić, mag. bibl.<smiles>C1CCC(C2CCCCC2)CC1</smiles>

Ivan Jelić, prof., dipl. knjižničar

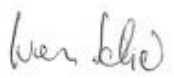

Mr. sc. Jadranka Lisek

Voditeljica Središnje knjižnice FER-a

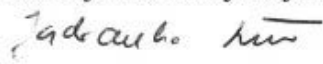

Slika 1. Zapisnik o reviziji knjižne građe Središnje knjižnice FER-a 
Nakon revizije nastavio se rad na obradi knjižne građe onih primjeraka knjiga koje su tijekom revizije „samoproduživane“, tj. djelatnici su koristili mogućnost da zadrže zadužene knjige i dostave ih na obradu (kodiranje, signiranje itd.) naknadno, a nastavlja se i rad na izlučivanju knjiga u zavodskim knjižnicama i njihovo premještanje u zajedničko spremište, što iziskuje dodatni rad jer se svakom primjerku mora mijenjati lokacija.

\section{Zaključak}

Iako je Centralna knjižnica ETF-a već pri svom osnutku ranih šezdesetih godina imala održiv plan koordinirane nabave, obrade i evidencije te je stvoren dobar temelj za daljnje poslovanje, zavodske publikacije nisu bile katalogizirane jedinstveno, a vrlo često i nisu bile bibliografski obrađene. Što zbog nedostatka stručnog osoblja, a što zbog neusuglašenog načina poslovanja, taj se trend nastavio u godinama koje su uslijedile. Prekretnicu je označilo uvođenje novog sustava za knjižnično poslovanje Koha 2011. godine, koji je svojim programskim karakteristikama uvelike olakšao odluku o provedbi, pa tako i realizaciju same revizije knjižne građe na Fakultetu. Nakon dugotrajnog i vrlo složenog revizijskog postupka pokazalo se da se podaci iz inventurnih lista knjižnica FER-a razlikuju od računalno evidentiranog broja primjeraka knjiga, a pred stručnim osobljem Središnje knjižnice stoji daljnji izazov provedbe revizije serijskih publikacija, pa tako i daljnjeg redovnog provođenja revizije knjižnične građe u skladu sa Zakonom.

\section{LITERATURA}

Pavunić, Marija. Struktura i djelovanje knjižnice Elektrotehničkog fakulteta u Zagrebu : magistarski rad. Zagreb : Prirodoslovno-matematički fakultet u Zagrebu, 1966.

Pola stoljeća nam je tek : 1961.-2011. : spomenica Središnje knjižnice Fakulteta elektrotehnike i računarstva. Zagreb : Fakultet elektrotehnike i računarstva, 2011.

Poslovni rječnik. Zagreb : Masmedia, 1992.

Pravilnik o Knjižnici FER-a. Zagreb: Knjižnica, 2002. (Interni dokument)

Pravilnik o reviziji i otpisu knjižnične građe. // Narodne novine 21, 503(2002). [citirano: 2015-01-15]. Dostupno na http://narodne-novine.nn.hr/clanci/sluzbeni/2002_03_21_503.html

Spomenica - 40. obljetnica Fakulteta elektrotehnike i računarstva : 1956.-1996. Zagreb: : Fakultet elektrotehnike i računarstva, 1996. 